Corresponding Author: Herliana Monika Azi Djogo; email: monikaherliana@gmail.com

Published: 7 February 2022

Publishing services provided by Knowledge E

(c) Herliana Monika Azi Djogo and Yulia M.K Letor. This article is distributed under the terms of the Creative Commons

Attribution License, which permits unrestricted use and redistribution provided that the original author and source are credited.

Selection and Peer-review under the responsibility of the IVCN Conference Committee.

\section{The Association Between Nutritional Status and Anemia in Adolescent Girls in Kupang City: A Cross-Sectional Study}

\section{Herliana Monika Azi Djogo* and Yulia M.K Letor}

Nursing Department, Faculty of Health, Citra Bangsa University, Kupang, Indonesia

\section{ORCID}

Herliana Monika Azi Djogo: https://orcid.org/0000-0003-1033-7988

\begin{abstract}
Anemia among adolescent females is a leading worldwide public health problem that should be given appropriate attention. Adolescent females are one of the major risk groups for anemia. This study aimed to determine the association between nutritional status and anemia in adolescent girls in Kupang City. A cross-sectional study design was employed. This research was conducted from July to August 2021 in Kupang City. Purposive sampling was used and 256 adolescent girls participated. A structured questionnaire was used to collect the data. The hemoglobin level and anthropometry measures were taken to determine the anemic and nutritional status of the females based on World Health Organization guidelines. Chi-square tests were used to analyze the data. The incidence of anemia among the adolescent girls was $64.5 \%$, while $31 \%$ of the girls were underweight. The results showed that there was no significant relationship between nutritional status and anemia among adolescent girls in Kupang city ( $p=0.06$ ). The notably high prevalence of anemia found in the adolescent girls was correlated with other health and wellness concerns. Anemia and undernutrition negatively affect academic performance, productivity, and general wellbeing of adolescents. The findings provide helpful information for nurses to initiate effective health promotion and prevention programs for adolescent nutritional status and anemia in the community.
\end{abstract}

Keywords: anemia, adolescent, females, nutritional status

\section{Introduction}

Anemia has become a serious global problem that affects the health of women of reproductive age. It is closely related to mortality and morbidity of women of reproductive age and impacts high-risk pregnancies [1]. There are 1.5 billion women of reproductive age suffering from anemia worldwide, and two-thirds of the incidence of anemia occurs in developing countries, including Indonesia $[2,3]$.

Adolescents in Indonesia - those between the ages of 10 and 19 - face the triple burden of malnutrition with the coexistence of undernutrition, overnutrition, and micronutrient deficiency. Approximately one-fourth of adolescents aged 13-18 years are stunted, 
contrast, another $16 \%$ of adolescents are overweight or obese. In addition, one-fourth of adolescent girls suffer from anemia [4]. According to Indonesian national health research, the prevalence of anemia in Indonesia was $21.7 \%$ in 2013 and had increased to $48.9 \%$ in 2018 [5]. Anemia in adolescent girls is caused by several factors, including lower food intake than recommended, especially foods containing iron, inadequate nutrition knowledge, and the menstrual cycle [6, 7,\& 8]. Anemia will impact decreasing concentration, learning achievement, adolescent fitness, productivity, and decreased immunity which can affect the health status of adolescents during this Covid-19 pandemic. The disruption caused by the COVID -19 pandemic will substantially impact youth's well-being, security, and future [9]. In addition, specifically, anemia experienced by young women will have a more severe impact, considering that they will become pregnant and give birth to a baby, thereby increasing the risk of maternal mortality, premature birth, and low birth weight [2].

Several previous studies have described the incidence of anemia in adolescents aged 15-17 years in Indonesia, Kuwait, Latin America. However, few studies were conducted on adolescent girls aged $>18$ years, especially in East Nusa Tenggara [10,11,12\& 13]. The incidence of anemia in adolescents should receive special attention because it has a sustainable impact on life. The government has launched a program to provide bloodsupplemented tablets for young girls in schools. Data from Indonesian basic Health Research 2018 showed that $76.2 \%$ of young women had consumed iron tablets, but there are $23.8 \%$ who have not consumed iron tablets [5]. Meanwhile, the proportion of adolescents (15-19 years) in Kupang City in 2018 was the second-largest population (14.75\%), after the proportion of adults (20.19\%). Young women often do not realize they have anemia; even though they know about it, they think anemia is not a health problem. Health in adolescents with anemia has not become the main focus for the government, which is still focusing on anemia in pregnant women [14]. This study aimed to determine the relationship between nutritional status and anemia among adolescent females in Kupang City.

\section{Methods and Equipment Study Design}

\subsection{Methods}

A cross-sectional study was conducted from July to August 2021 in The Citra Bangsa University, located in Kupang, East Nusa Tenggara Province of Indonesia. 


\subsection{Population, sample and sampling}

The participants of this study were adolescent girls aged $18-23$ years in Citra Bangsa University. The total Population was 625 adolescent girls. The proportion of anemia among adolescents based on the previous study in Kendari Indonesia was 41. 7\% [13]. Based on this information, The total of participants using the sample size formula by Daniel [15] with the expected prevalence or the expected proportion $(0.41 \%)$ was 233. Then, the final sample size was 256 , adding a $10 \%$ non-response rate due to an invasive procedure. The sample of this study was selected using the purposive sampling technique. The inclusion criteria in this study were 1) adolescent girls who do not menstruate at least one week from the first day of the period, 2) adolescent girls who do not have a chronic disease. Adolescents with chronic disease will experience growth problems and anemia that will impact anemia and anthropometric measurement.

\subsection{Instruments}

Data were collected using a questionnaire adapted from the Indonesian demographic and health survey [15], anthropometry: weight, height, and Body Mass Index calculator by $\mathrm{WHO}$ [16], and the prevalence of anemia measurement using a hemoglobin meter for anemia.

The questionnaire consists of demographic factors: the age of adolescence, the education of mother and father, occupation of mothers and fathers. The education of mother and father was divided into basic, middle, and higher education based on Indonesian Management of National Education [17].

Anthropometric measurements; Weight was measured with the weighing scale to the nearest 0.1 kilograms. The height of participants was measured with a stadiometer to the nearest 0.1 centimeters. The body mass index was determined using the weight and height of participants by calculating the weight $(\mathrm{kg}) /$ and height $(\mathrm{m} 2)$. Participants were classified as underweight, normal, overweight, or obese based on the WHO BMI calculator [17].

The hemoglobin level of participants was determined using a hemoglobin meter for anemia. A drop of the capillary blood was obtained from the middle finger after a prick and was place into the hemoglobin meter strip. Based on WHO classification, $\mathrm{Hb}$ Levels below eight $\mathrm{g} / \mathrm{dL}$ were classified as severe anemia, 8-10.99 $\mathrm{g} / \mathrm{dL}$ as moderate anemia, 11-11.9 $\mathrm{g} / \mathrm{dL}$ as mildly anemic, and $\mathrm{Hb}$ of $12 \mathrm{~g} / \mathrm{L}$ and above was classified as normal [18]. 


\subsection{Procedure}

When the president of Citra Bangsa University approved the study, the researcher collected data by directing interviewed adolescence about demographic factors. This procedure was followed by anthropometric measurement and hemoglobin test. Before collecting data, the researcher always checked the materials and equipment: weight scale and height stand, HemoCueHB 301 machine, and sanitary materials such as cotton, alcohol, and gloves.

Weight measured were using weighing scale to the nearest 0.1 kilograms. The height was measured with a stadiometer to the nearest 0.1 centimeters. The nutritional status was calculated using the BMI calculator.

Finger pricked after wiping finger with alcohol-soaked cotton for hygiene and safety measures, and then the pricked finger was gently pressed to get a sample of blood. The sample blood was put on Hemoglobin stick and inserted into hemoglobin meter for anemia machine. Hemoglobin level was read and noted on the questionnaire. All respondents signed the informed consent before data were collected. When each respondent had done the questionnaire, the anthropometric measurements, and the hemoglobin level test, the result was collected and used for statistical correlation.

\subsection{Data Analysis}

Descriptive statistic was used to describe characteristics of respondents. A Chi-square test was used to determine the relationship between nutritional status and anemia using SPSS version 22.0.

\subsection{Ethical Considerations}

The approval was given by the Ethical Review Board of Citra Bangsa University (EC No.001/A/2021). The mothers who were willing to participate in this study were given informed consent.

\section{Results}

Characteristic of respondents

Others ${ }^{1}$, cleaning, police officer, carpentry, teaching and banking. 
TABLE 1: Characteristics of respondents based on demographic data, nutritional status, and anemia $(\mathrm{n}=$ 256)

\begin{tabular}{|c|c|c|}
\hline Characteristic & $\mathbf{N}$ & $\%$ \\
\hline \multicolumn{3}{|c|}{ The age of adolescence (Range, Mean \pm SD) $(18-23,20.56 \pm 1.873$} \\
\hline \multicolumn{3}{|c|}{ Mothers Level of education } \\
\hline Basic education (complete nine years education) & 118 & 46.1 \\
\hline $\begin{array}{l}\text { Middle education (complete three years } \\
\text { education) }\end{array}$ & 85 & 33.2 \\
\hline $\begin{array}{l}\text { Higher education (complete one or more than four } \\
\text { years education) }\end{array}$ & 53 & 20.7 \\
\hline \multicolumn{3}{|l|}{ Fathers level of education } \\
\hline Basic education & 26 & 10.2 \\
\hline Middle education & 127 & 49.6 \\
\hline Higher education & 103 & 40.2 \\
\hline \multicolumn{3}{|l|}{ Mothers Employment } \\
\hline Trading & 45 & 17.5 \\
\hline Civil servant & 90 & 35.2 \\
\hline Farming & 21 & 8.2 \\
\hline Unemployed (house wife) & 100 & 39.1 \\
\hline \multicolumn{3}{|l|}{ Father employment } \\
\hline Trading & 15 & 5.9 \\
\hline Civil servant & 119 & 46.5 \\
\hline Farming & 60 & 23.4 \\
\hline Mason & 18 & 7 \\
\hline Others ${ }^{1}$ & 44 & 17.2 \\
\hline \multicolumn{3}{|l|}{ Nutritional status } \\
\hline Normal & 177 & 69 \\
\hline Underweight & 79 & 31 \\
\hline \multicolumn{3}{|l|}{ Prevalence of Anemia } \\
\hline Anemic & 165 & 64.5 \\
\hline Non anemic & 91 & 35.5 \\
\hline
\end{tabular}

Table 1. It shows that the age ranged of participants was 18 to 23 years, with the average age of adolescent girls was 20.56 (standard deviation \pm 1.873 ). The majority of the mothers (46.1\%) and fathers (49.6\%) had basic and middle education. There are $39.1 \%$ of mothers and $46.5 \%$ fathers were unemployed and civil servants. The anthropometric measures showed that more than half (69 \%) of adolescent girls had normal body mass index (BMI). Nevertheless, 31\% of adolescent girls are underweight. The prevalence of anemia shows that most adolescent girls (64.5\%) were anemic, while $35.5 \%$ had an average hemoglobin level. 
TABLE 2: The relationship between nutritional status and the prevalence of anemia among adolescent girls in Kupang City $(n=256)$.

Nutritional status
Normal
Underweight

\begin{tabular}{|l|l|l|l|l}
\multicolumn{4}{c}{ Prevalence of anemia } & P \\
\hline & Anemic & \multicolumn{2}{c|}{ Non anemic } & \\
N & $\%$ & N & $\%$ & \\
109 & 61.6 & 68 & 38.4 & 0.06 \\
\hline 58 & 73.4 & 21 & 26.6 & \\
\hline
\end{tabular}

Table 2. This table presents the nutritional status and the prevalence of anemia. A majority (61.6\%) of anemic participants had normal BMI, while $73.4 \%$ were underweight. The chi-square test shows no significant relationship between nutritional status and the prevalence of anemia with a p-value- 0.06 .

\section{Discussion}

The overall mean age of participants was $20.56 \pm 1.873$ years with ranged from 18 to 23 years. The majority of the participants were in late adolescence (18-23 years). The finding was similar to a study conducted in Southeast Ethiopia among adolescent girls where the most $(22 \%(95 \% \mathrm{Cl}(17.6-26.1))$ of the participant were in late adolescence. Late adolescents were more likely to have anemia as compared to early adolescents [6]. In this study, most participants were in their late adolescence, which could be attributed to most adolescents' typical demographics in Indonesia [4\&15].

Malnutrition refers to deficiencies, excesses or imbalances in a person's energy intake and nutrients [19\&20]. Most of the participants in this study had normal nutritional status, while there are adolescents were underweight. A different study conducted in Ghana and China showed similar results. Most adolescent girls had a normal body mass index, with a few of them being underweight and overweight [7\& 21]. Although most of the participants had a normal nutritional status, there were still adolescents with underweight. The finding aligns with the Indonesian basic health research 2018 data that describe $32.5 \%$ of adolescent females in East Nusa Tenggara were underweight [5]. Girls maybe impacted by issues surrounding body image and appearance and the expectation to be thin. Often, girls also face the burden of household work and helping care for younger siblings [4]. Being Underweight can also be caused by inadequate food intake, diet low in diversity, and inadequate consumption of fruits and vegetables. Eating less than three times a day and consuming fewer fruits and vegetables can cause young women to experience malnutrition [23\&24]. On the other hand, the Nusa Tenggara province, especially Kupang City, had culturally and traditionally valued patriarchy. 
Women tend to accept that men are the ones who decide everything for the family because they are considered wiser and smarter, no exception for eating [25].

The incidence of anemia in adolescent girls can be caused by several factors, including inadequate knowledge about nutrition, the menstrual cycle and lack of iron consumption [2 \& 4]. The prevalence of anemia among adolescent girls was found at $64.5 \%$ in this study. Several studies conducted in Bhutan and Kuwait showed a similar finding [22\&23], where most adolescent girls suffered anemia. The incidence of anemia in this study can be associated with inadequate nutritional intake and the menstrual cycle experienced. In addition, Young women often do not realize that they have anemia. Even though they know about the condition, they think that anemia is not a health problem.

Most of the participants (61.6 \%) had a normal Body Mass Index suffered anemia, while $73.4 \%$ of the underweight were anemic. The previous study in Ghana also did a similar finding. The result showed that most (50. 3\%) of the adolescents in Ghana were anemic. This study's determination showed that most participants $(72.7 \%)$ underweight were anemic, followed by those with a normal BMl of $60.5 \%$, and $50 \%$ of the overweight were also anemic. A similar finding showed the underweight women are more likely to have iron deficiency and iron-deficient erythropoiesis reflected by low haemoglobin levels and subsequent anemia [28].

This finding can be explained from several points of view. Firstly, the intake of nutrients in the body is less so that the nutritional needs in the body are not met, especially iron. Iron is one of the essential components in Haemoglobin formation; a lack of iron intake in the body will cause reduced red blood cell-forming material, so red blood cells unable to supply oxygen lead to anemia. Secondly, lack of protein consumption such as meat and fish and inadequate consumption of fruits and vegetables also contribute to anemia in adolescents. However, they had a normal nutritional status. Lastly, the consumption of junk food also becomes a habit in adolescents. In the present study, no significant association was observed between the incident of anemia and nutritional status, which is consistent with the several studies in Ethiopia and Pakistan that showed no significant relationship between nutritional status and anemia [24\&25].

\section{Conclusion}

Anemia among adolescent girls is still public health in Indonesia. More than half of the participants were anemic and underweight. However, there is no significant relationship between nutritional status and anemia. Anemia and undernutrition negatively affect 
the academic performance, productivity, and general wellbeing of adolescents. The finding provided helpful information for nurses to initiate effective health promotion and prevention of adolescent nutritional status and anemia in the community.

\section{Funding}

This study was supported by the Directorate General of Higher Education, Ministry of Education and Culture of the Indonesian Republic with the funding number 1264/LL15/KM/2021.

\section{Acknowledgment}

The authors would like to thank the Directorate General of Higher Education, Ministry of Education and Culture of the Indonesian Republic, for funding this study. The authors acknowledge the study participants and data collectors who helped the author finished this study.

\section{Conflict of interest}

The author have no conflict of interest to declare.

\section{References}

[1] World Health Organization. Anaemia. Geneva: WHO; 2021. Available from: https://www.who.int/health-topics/anaemia\#tab=tab_1

[2] WHO. The global prevalence of anaemia in 2011. Geneva: WHO; 2011. Available from: https://apps.who.int/iris/bitstream/handle/10665/177094/9789241564960_eng.pdf

[3] Ouédraogo S, Koura GK, Bodeau-Livinec F, Accrombessi MMK, Massougbodji A, Cot M. Maternal anemia in pregnancy: Assessing the effect of routine preventive measures in a malaria-endemic area. The American journal of tropical medicine and hygiene. 2013;88(2):292.

[4] UNICEF. Behaviour change communication strategy: Improving adolescent behaviour. UNICEF Indonesia; 2021.

[5] Ministry of Health of Republic Indonesia. Indonesian Basic Health Research in 2018. 2018. Available from: https://www.kemkes.go.id/folder/view/01/structure-publikasipusdatin-profil-kesehatan.html 
[6] Engidaw MT, Wassie MM, Teferra AS. Anemia and associated factors among adolescent girls living in Aw-Barre refugee camp, Somali regional state, Southeast Ethiopia. PLoS One. 2018;13(10):1-12.

[7] Zhu Z, Sudfeld CR, Cheng Y, et al. Anemia and associated factors among adolescent girls and boys at $10-14$ years in rural western China. BMC Public Health. 2021:1-14.

[8] Balci YI, Karabulut A, Gürses D, Çövüt IE. Prevalence and risk factors of anemia among adolescents in Denizli, Turkey. Iranian journal of pediatrics. 2012;22(1):77-81.

[9] UNICEF. COVID-19 dan Anak-anak di Indonesia. 2020. Available from: https://www.google.com/url?sa=t\&rct=j\&q=\&esrc=s\&source=web\&cd=\&ved= 2ahUKEwjQ5_vxcfsAhUkXHwKHdiJAIEQFjACegQIAhAC\&url=https\%3A\%2F\% 2Fwww.unicef.org\%2Findonesia\%2Fsites\%2Funicef.org.indonesia\%2Ffiles\% 2F2020-05\%2FCOVID-19-dan-Anak-anak-di-Indonesia-2020_1.pdf

[10] Andari, S., \& Wirjatmadi, B. Hubungan tingkat konsumsi protein, vitamin c, zat besi dan asam folat dengan kejadian anemia pada remaja putri SMAN 4 Surabaya. Amerta Nutrition. 2019;3(3):135-41.

[11] Shaban L, Al-taiar A, Rahman A, Al-sabah R. Anemia and its associated factors among adolescents in Kuwait. Scientific reports. 2020:1-9. http://dx.doi.org/10.1038/s41598020-60816-7

[12] Sumarlan ES, Windiastuti E, Gunardi H. Iron status, prevalence and risk factors of iron deficiency anemia among 12- to 15-year-old adolescent girls from different socioeconomic status in Indonesia. Makara Journal of Health Research. 2018;22(1):46-52.

[13] Kaimudin N, Lestari H, Afa J. Skrining dan determinan kejadian anemia pada remaja putri sma negeri 3 kendari tahun 2017. Jurnal Ilmiah Mahasiswa Kesehatan Masyarakat. 2017;2(6):185793.

[14] Rahmawati KD. Analisis faktor penyebab kejadia anemia gizi besi pada remaja putri di sman 2 kota bandar lampung tahun 2011 [Skripsi]. 2011.

[15] Daniel WW. Biostatistics: A foundation for analysis in the health sciences. $5^{\text {th }}$ ed. 1991.

[16] National Population and Family Planning Board (BKKBN), Statistics Indonesia (BPS) Ministry of Health, (Kemenkes). Indonesia 2017 DHS. 2018. Available from: https://dhsprogram.com/pubs/pdf/FR342/FR342.pdf

[17] WHO EMRO. Body mass index calculator information resources. WHO; 2021. Available from: http://www.emro.who.int/nutrition/information-resources/bmicalculator.html 
[18] Indonesia Ministry of Education and Culture. The management of national education in 2014/2015 at a glance. 2016. Available from: http://publikasi.data.kemdikbud.go.id/uploadDir/isi_6549DA84-7A7F-44B5-AD22829B1F002A4F_.pdf

[19] WHO. Haemoglobin concentrations for the diagnosis of anaemia and assessment of severity. Vitam nad Miner Nutr Inf Syst Geneva, Switz World Heal Organ; 2011. Available from: http://scholar.google.com/scholar?hl=en\&btnG=Search\&q=intitle: Haemoglobin+concentrations+for+the+diagnosis+of+anaemia+and+assessment+ of+severity\#1

[20] Abitew DB, Yalew AW, Bezabih AM, Bazzano AN. Predictors of relapse of acute malnutrition following exit from community-based management program in Amhara region, Northwest Ethiopia: An unmatched case-control study. PLoS One. 2020;15(4).

[21] WHO. Fact sheets - Malnutrition. WHO; 2021. Available from: https://www.who.int/news-room/fact-sheets/detail/malnutrition

[22] Gosdin L, Tripp K, Mahama AB, et al. Predictors of anaemia among adolescent schoolchildren of Ghana. J Nutr Sci. 2020;9:1-11.

[23] Canuto R, Da Silva Garcez A, Kac G, Cabral De Lira PI, Anselmo Olinto MT. Eating frequency and weight and body composition: a systematic review of observational studies. Public Health Nutr. 2017.

[24] Pengpid S, Peltzer K. The prevalence of underweight, overweight/obesity and their related lifestyle factors in Indonesia, 2014-15. AIMS Public Health. 2017;4(6):633-49.

[25] Goa MY, Rachmawati IN, Ungsianik T. Paternal self-efficacy in the patriarchal culture of Kupang city, Indonesia. Enfermería Clínica. 2021;31:S457-60.

[26] Shaban L, Al-Taiar A, Rahman A, Al-Sabah R, Mojiminiyi O. Anemia and its associated factors among Adolescents in Kuwait. Scientific Reports. 2020;10(1):19. dx.doi.org/10.1038/s41598-020-60816-7

[27] Campbell RK, Waid JL, West KP. Epidemiology of anaemia in children, adolescent girls, and women in Bhutan. Maternal \& child nutrition. 2018;14(Apr):1-9.

[28] Khan ZA, Khan T, Bhardwaj A, Aziz SJ, Sharma S. Underweight as a risk factor for nutritional anaemia - A cross-sectional study among undergraduate students of a medical college of haryana. Indian Journal of Community Health. 2018;30(1):63-9.

[29] Seyoum Y, Humblot C, Nicolas G, Thomas M. Iron deficiency and anemia in adolescent girls consuming predominantly plant-based diets in rural Ethiopia. 2019:6-11. 
[30] Khan A, Chawla RK, Wang C, Guo M. Risk factors associated with anaemia among adolescent girls: A cross sectional study in District Peshawar, Pakistan. J Pakistan Med Assoc. 2019;69(11):1591-5. 